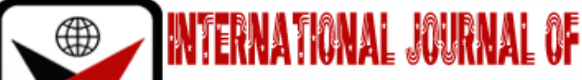

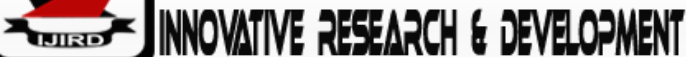

ISSN 2278 - 0211 (Online)

\section{Accessing the Availabilities, Utilization and Attitude of Teachers in E-learning Technologies for the Teaching and Learning of TVET Programmes in the North-west Nigeria}

\author{
\begin{tabular}{c}
\hline Dr. Emmanuel J. Paiko \\
Lecturer, School of Technical Education, \\
Federal College of Education (Technical), Gusau, Zamfara State, Nigeria \\
\hline
\end{tabular}
}

\begin{abstract}
:
The study focused on Accessing the Availabilities, Utilization and Attitude of Teachers in E-learning Technologies for the Teaching and Learning of TVET Programmes in the North-west Nigeria Two research questions were developed and answered in line with what the study sought to find out. Also two null hypotheses were formulated and tested at the probability of 0.05 levels of significance. The study made use the questionnaire consists of fifty questions, divided into four sections with five printed pages. The questions included close-ended as well as open-ended questions to capture respondents' experiencesregarding the application of the e-learning technologies in their core business of teaching in the Nigerian COEs. The instrument was face validated by the researcher's senior colleagues in the school of Technical Education and to ensure reliability of the items, they were pilot tested in two (2) Colleges outside the selected COEs within the study area. The entire population for the study was 98,377 Students across the colleges 2000 obtained from the sampled colleges selected from the study area. Three hundred and twenty (100) respondents were sampled out of the total population using stratified simple random sampling technique. The data collected for the study were analyzed using descriptive statistics (mean and Standard deviation) to answer the research questions raised where $t$ test statistical analysis was employed by the researcher to test the null hypotheses. The findings of the study revealed that the potentials for realadoption of e-learning technologies for the teaching and learning of TVET programmes in the Nigerian COEs are great, also revealed that the level of e-learning technologies utilization varies among the research participants, and over $75 \%$ of participants are happy to use e-learning technologies for educational purposes.
\end{abstract}

Keywords: Accessing, availabilities, utilization, attitudeofteachers, e-learning, technologies, teaching andlearning

\section{Introduction}

In the recent time, e-learning has become an integrated part of our lives and the educational process; it is now a necessary tool for preparing people to participate in the technologically driven global environment. E-Learning is a very broad term for electronic method of learning such as computer-based training, web-based training or Internet-based training. It is the use of Information and Communication Technologies (ICTs) to enhance and/or support learning in tertiary education (OECD, 2005). It has become predominant in both secondary and post-secondary education, asudas in corporate learning in most countries (e.g. USA, India, and Canada). E-learning has been widely accepted as it is seen as a form of knowledge transfer which is independent of time and location. Students, teachers, lecturers, entrepreneurs, policy makers and e-learning practitioners have been able to use technology to make progressive change at both institutional and system-widelevels.

In Nigeria today, the integration of e-learning technologies to support the traditional form of classroom teaching and learning has been given much prominence of recent as both private and government aretaking initiatives to integrate e-learning technologies into the learning system. Policy initiatives since 1988, according to Yusuf (2007) have been targeted to integrate and explore the opportunitiesthat ICT can offer through e-learning in the Nigerian school system at a variety of levels (e.g., policy emphasis, curricular emphasis, teacher development plans in ICT and institutional investment, etc.). Similarly, a number of initiatives according to Lawal, et al., (2017) have been set up to integrate e-learning technologies in the nation's school system, including National Policy on Computer Education, National Policy on Information Technology, Establishment of National Information Technology DevelopmentAgency (NITDA).

However, for almost two decades since then, little impact of e-learning technologies has been felt in the Nigerian school system (Lawal, 2017 and Yusuf, 2007). Since 1988, the policy initiatives to encourage the use of e-learning technologies in the Nigerian schools have not yielded the needed results of improving teaching and learning that will produce a better educated work force. The changes noted through e-learning technologies in the Nigerian school are much smaller than expected, in spite of the fact that potentials for real change are great (Lawal, 2017 and Yusuf, 2007). Furthermore, 
initiatives and the rising investment in e-learning technologies to teach TVET programmes in technical colleges do not guarantee its effective use or what impact it will have (Lawal, et al., 2017). Even in the Nigerian COEs where the commitment has been significant and e-learning technologies are seemingly ubiquitous, its use in classrooms is highly variable and often underwhelming (Ajayi and Lawal 2014). Indeed, Ajayi and Lawal survey of lecturers and students of Nigerian COEs found no correlation between student - computer ratio and use of e-learning technologies in classrooms. Teachers differ on whether they feel e-learning technologies makes their jobs easier or adds to their workloads. While teachers may recognize the positive potential that e-learning technologies can offer in the classroom, that potential is rarely realized (Onu, 2011).

In terms of competencies required to use the e-learning technologies for teaching, researches (e.g. Lawal, et al., 2017 \& Ajayi and Lawal, 2014) have shown that most teachers educators in the Nigerian COEs lack, Technological Pedagogical Content Knowledge (TPCK) i.e. the skill and knowledge on how to adopt the e-learning technologies into their classrooms for teaching and learning purposes.Ajayi and Lawal also claim that, traditional teaching methods have dominated thelecture delivery and have been the adopted practices in the Nigerian COEs and that, pre-and in-service teachers have insufficient access to digital technologies and the internet in their classroomsand other centres within their schools premises in the Nigerian teacher traininginstitutions.

\subsection{Problem Statement}

The teaching and learning of TVET programme in the Nigerian COEs are intended to produce teachers with relevant technologies and related sciences and the acquisition of practical skills, attitudes, understanding and knowledge relating to occupations in the sectors of economic and social life. For this reason, effective TVET education programmes within the purview of curriculum delivery of the World Council for Curriculum and Instruction (WCCI, 2012), which calls for a paradigm shift in the delivery system to match the new knowledge, attitudes, skills and technologiesthat are emergent to meet the demands of the knowledge economy and global competitiveness arehighlyimportant.

Since curriculum is a vehicle through which educational goals are attained and methods of deliveryare a component of the curriculum, there is need for employment of effective delivery systems ofTVET related programmes in the Nigerian COEs so as to produce efficient TVET teachers who arelocally and globally competent, effective and relevant. E-learning which is electronic learning is oneof such effective curriculum delivery systems that have been identified by researchers. In fact, elearning in Nigeria tertiary institutions has recently continued to grow at unprecedented rate but withalot of challenges.

Researchers (e.g. Ekesionye \& Okolo, 2011) have proven that e-learning approach of curriculum delivery is superior to the traditional classroom method of teaching and learning. Other researchers(Onwuagboke et al., 2014; Yusuf, 2014; Ajayi and Lawal 2014; Owolabi et al, 2013;) affirm that though, e-learning approach is not a substitute but a supplement to the traditional classroom teachingand learning. They prove that the inclusion of e-learning technologies in education can very well improve student achievements. They added that the levels of improvement largely depend on the accessibility and utilization of the e-learning technologies; the way the technology is infused into the teaching methods and the design of instruction (Lawal, 2017 and Ekesionye \& Okolo,2011).

However, owing to the importance of the TVET education highlighted above, little has been done toinvestigate and assess the level of availability, accessibility and utilization of these e-learning technologies in the teaching and learning of TVET programmes in the Nigerian COEs. Additionally, the factors identified by various research listed above may not apply to all COEs inNigeria, as different tiers of tertiary institutions in Nigeria have varied policy and curricular emphasis, teacher development plans and institutional investment. That is the problem this research idesigned to tackle.

\subsection{Objectives}

- Determine the extent to which e-learning technologies are available and utilized for the teaching and learning of TVET programmes in the Nigerian COEs across the North-Westgeopolitical zone of the country

- Determine the extent of attitude to which e-learning technologies are utilized for the teaching and learning of TVET programmes in the Nigerian COEs across the North-Westgeopolitical zone of the country

\subsection{Research Questions}

- In what extent are the e-learning technologies available and utilized for the teaching and learning of TVET programmes in the Nigerian COEs?

- What is the influence of TVET educators' attitude towards the utilization of e-learning technologies for the teaching and learning of TVET programmes in the Nigerian COEs?

\section{Literature Review}

\subsection{Concept of E-learning}

E-Learning is a very broad term for electronic method of learning which is closely associated withinternet -based learning in general. E-learning education is the wholesome integration of moderntelecommunication equipment and ICT resources, particularly the internet, into the education system. Various concepts of e-learning have been given. E-learning refers to the use of information and communication technologies (ICTs) to enhance and/or support learning in tertiary education (OECD, 2005).

Distance education has made e-learning more popular as it has become a veritable way to bridge the distance between the teacher and the learner, between the writer and the speaker (Obuh, 2010). Obuh also views e-learning as 
comprising all forms of electronically supported teaching and learning. He contends that e-learning is to brick wall classroom learning, what mobile phone is to analogue fixed telephone line. To him, whereas the block wall classroom is situated at a place whereteachers and students physically meet and interact, e-learning is diffused, capable of taking place anywhere and anytime, withoutface-to-face interaction between the teacher and students.

E- Learning has become synonymous with the latest approach to providing high quality educational offerings. ELearning according to Seufert et al., (2001) is defined as technology - supported learning and the delivery of content via all electronic media. E-Learning places greater emphasis oninteraction and communication. Interaction with the instructor and with other students which may occur through internet-channels, videoconferencing or teleconferencing, in asynchronous (email orbulletin board) sessions or synchronous (e. g., chat room, whiteboard, application sharing) sessions.E-learning is a term applied to systems for distance learning, software to support students taking acampus -based course, or simply online documentation for teaching(Seufertetal., 2001).

In summary, e-learning is viewed by various authors according to their personal knowledge and perspectives, but they all seem to agree that e-learning comprises all forms of electronically supported learning and teaching which are procedural in character and aim to effect the constructionof knowledge with reference to individual experience, practice and knowledge of the learner. This view is supported by Ravichandra (2005), who said that E-learning in the broadest sense concernsitself with learning that occurs on line through the internet, off the using the CD-ROM or other facilities such as radio, television and telephony. E-learning encompasses learning at all levels, both formal and non-formal that uses an information network, the internet, an intranet (LAN) or extranet (WAN), whether wholly or in part, for course delivery, interaction, evaluation and facilitation which Salawudeen (2010) explained, uses network technologies to create, deliver and facilitate learningany time, and anywhere.

\subsection{Forms of E-learningApproach}

E-learning has evolved since technology was first used in education. There is a trend to move towards blended learning services, where computer-based activities are integrated with hands-on, face-to-face, or classroom-based situations. Various methods in e-learning include:

\subsubsection{Classroom 2.0}

This refers to using an online multi-user virtual environment (MUVE) to connect schools across geographical frontiers. Known as 'e-Twinning', computer-supported collaborative learning (CSCL) and the Internet allow learners in one school to communicate with learners in another that they would not get to know otherwise, enhancing educational outcomes and cultural integration.

\subsubsection{E-learning 2.0}

E-learning 2.0 is a type of computer-supported collaborative learning (CSCL) system that developed with the emergence of Web 2.0. From an e-learning 2.0 perspective, conventional e-learning systems were based on instructional packets, which were delivered to students using assignments. Assignments were evaluated by the teacher. In contrast, the new e-learning places increased emphasis on social learning and use of social software such as blogs, wikis, podcasts, virtual worldsand social networks.

Technologies including blogs, collaborative software, e-Portfolios, virtual classrooms, audio, video and tools like computers, laptops, tablets are increasingly used to support e-learning. With the increased use of mobile phones, a new method in e-learning being explored is the use ofmobile phones for different types of learning and this is referred to as Mobile learning or m- Learning.

\subsection{Prospectsand Benefits of using E-Learning Technologies in the COEs System}

According to Ogboji(2011:340):

- E-learning makes teaching and learning easy and reduces stress for both lecturers andstudents.

- It is convenient for students to review their course materials anytime and get resultfaster than it used to be with the traditional system.

- It provides opportunity for a course designer to present to students through a singleinterfaceall the requirements and components of a course of training.

- It provides additional resources including reading materials and links to outside resources in internet and libraries.

- It provides examination and self-assessment quizzes which can be scoredautomatically.

- It provides electronic communication such as e-mail and threaded discussions forboth lecturersand students.

Mole (2011) adds that e-learning has a capacity to address the scarcity of teaching and research materials in the libraries of institutions of higher learning. It would allow students, lecturers and researchers to share their own research outputs with the global community and improve the provision of current e-books, e-journals and other library resources, enhance access of academic libraries to global library and information resources; enhance scholarship, research and lifelong learning through the establishment of permanent access to shared virtual archival collections. We can also that elearning equips students with the digital skills for the job market.

Furthermore, e-learning makes the learner to be dependent and accessible to learning experiences locally and globally through the internet by the best universities and research institutions in the world. Administratively, e-learning project offers the university opportunity to publish information on the internet, such as latest events on campus, list of newly 
admitted students, online registration ofstudents and course and payment of fees.

\subsection{E-Learning in the Context of TVET}

Due to the flexibility, simplicity and affordability of ICT facility in all areas of human endeavour, itsapplication in the field of education is gaining popularity among educational organisations and their stakeholders (Tondeur, van Keer, van Braak, \& Valcke, 2008). TVE in this context is not an exception too; the use of ICTs to foster employability skills is highly recommended (Saud, et-al, 2011).

However, the use of ICTs toward the preparation of TVE graduates; and in their mode of training should also incorporate the use of e-learning in teaching learning process. E-learning (ICT based learning environment), enables students, trainees and teachers/instructors interact virtually withoutphysical contact(Bappa-Aliyu, 2012).\ The consensus among educational practitioners is that e-learning is 'the use of processes and technologies to create, distribute, manage, and enable learning via an electronic network.

By the implication of the above definition, one may wonder how e-learning environment that is similar to distant learning in designed and presentation can support the nature of courses offered inTVE, considering the fact that majority of the courses require hands-on activities (practical activities). Butabove definition offered some explanation to that effect, as to e-learning environmentand its flexibility to allow for the development of course content by lecturers/instructors, in order to give both teacher and student an opportunity to upload and download course material (interaction) and of course the material dealing with practical (hands-on) activities; such as machining,measurement and so on. E-learning in the delivery of hands-on activities has found application inengineeringeducation (Gupta, 2002).

\subsection{E-learning Technologies in the Nigerian TertiaryInstitutions}

Most tertiary institutions in Nigeria were cognizant of the special educational needs of learners with disabilities in their institutions. E-learning has been encouraged for the purpose of making learningeasier for students with special needs. Closed circuit television (CCTV), overhead projectors, slides,transparencies and magnifiers were made available to students for reading purposes. Computers with special devices for operating complex functions were made available to students and staff with visual impairments in Departmental and College offices. How adequate were the e-learning equipment and materials?

The major problems of e-learning faced by students in Nigeria's tertiary institutions were:

- Inadequate supply of e-books to enhance their studies. After listening to lectures through radio broadcast, ebooks should complement the lectures. Students with visual impairmentsparticularly require e-books.

- Universities and COEs in most cases do not have enough computers and special reading devices for students to use.

- Tertiary institutions in Nigeria were yet to incorporate Television conferencing. In most continents like the USA, Europe and Asia, lectures and examinations may be arranged and conducted on-line. Examination results are released to individual students almost immediately. Nigeria's tertiary institutions are notyet there.

To fill the above identified gap, this research is aimed at assessing the availability and utilization of e- learning technologies and investigating the obstacles to the successful adoption of the e-learning technologies in teaching and learning of TVET programmes from lecturer's perception across theNigerian COEs in the North-Western Zone of the country.

\section{Methodology}

In this research, a mixed methodology was applied where both quantitative and qualitative methods is used to address the research questions, the researchers collected data from respondents through a survey method, to ascertain the level of availability and utilization of the important e-learning technologies that will improve the teaching and learning of TVET programmes in the Nigerian COEs. The researchers used some selected COEs across the North-Western part of the country that offers TVET programmes as case study.

The questionnaire consists of fifty questions, divided into four sections with five printed pages. The questions included close-ended as well as open-ended questions to capture respondents' experiencesregarding the application of the elearning technologies in their core business of teaching in the Nigerian COEs. The close-ended questions were statistically analyzed by means of descriptive statistics while answers to the open-ended questions were analyzed using comparative analysis.

The questionnaires were constructed using relevant information from the web and the reviewed academic literature concerning the importance and application of e-learning technologies into teaching and learning of TVET programmes at COEs level. Questions from the questionnaire were closely examined by the researchers and other senior colleagues at the COEs level, and changed until the questions clearly stressed an answer. Two TVET chief lecturers of a COE in Nigeria reviewed the questionnaires to see if they were understandable and meaningful. The questionnaires were pilot tested by four other TVET lecturers of different ranks of the same institution before the actual distribution. The reliability of the data depends mainly on the design quality of the questionnaire andits administration. The validity was ascertained via facial validity by the TVET lecturers that reviewed the questionnaire.

In order to be sure of the research validity before the questionnaire was launched and distributed to target respondents, appropriate sampling techniques was devised. A purposive sampling technique would be employed to select the TVET teacher educators to participate in the research.

The purposive sampling method used in this regard is described below:

- The COEs to be selected from the North-Western part of Nigeria must have two - third of all obtainable TVET 
programmes therein fully accredited by the National Commission for Colleges of Education (NCCE) or any other accreditation agency recognized by the FederalMinistry of Education.

- $\quad$ Participants (i.e., the TVET educators) to participate in the survey must be academic staff of a COE in the North-West part of Nigeria for at least three years from date of research.

- By these specialized sampling techniques, the researchers were be able to distribute the questionnaires to the target respondents and established a balance view point across board.

\section{Discussion}

The quantitative and qualitative data collected using the 'Status of E- learning Technologies for the Teaching and Learning of TVET Programmes in the Nigerian Colleges of Educations' questionnaire from the survey. It also presents its corresponding analysis and interpretations.

4.1. Perception of TVET Educators on the Level of Availability of the Studied E-Learning Technologies for the Teaching and Learning ofTVET Programmes in the Nigerian Coes

\begin{tabular}{|c|c|c|c|c|c|c|c|c|c|}
\hline $\mathbf{S} / \mathbf{N}$ & Facilities & \multicolumn{2}{|c|}{ Available } & \multicolumn{2}{|c|}{ Not Available } & \multicolumn{2}{|c|}{ Missing } & \multicolumn{2}{|c|}{ Total } \\
\hline & & $\mathbf{F}$ & $\%$ & $\mathbf{F}$ & $\%$ & $\mathbf{F}$ & $\%$ & $\mathbf{N}$ & $\%$ \\
\hline 1 & Computer System & 90 & 96.8 & 3 & 3.2 & 0 & 0 & 93 & 100 \\
\hline 2 & Laptop & 88 & 94.6 & 4 & 4.3 & 0 & 0 & 93 & 100 \\
\hline 3 & College email Account & 20 & 21.5 & 70 & 75.3 & 3 & 3.22 & 93 & 100 \\
\hline 4 & Power Point Package & 90 & 96.8 & 3 & 3.22 & 0 & 0 & 93 & 100 \\
\hline 5 & Moodle & 3 & 3.22 & 67 & 72 & 23 & 24.7 & 93 & 100 \\
\hline 6 & IPod \& Apps & 10 & 9.3 & 52 & 56 & 31 & 33.3 & 93 & 100 \\
\hline 7 & Learning objects(LOs) & 19 & 20.4 & 47 & 50.5 & 27 & 29 & 93 & 100 \\
\hline 8 & Skype & 12 & 12.9 & 36 & 38.7 & 45 & 48.4 & 93 & 100 \\
\hline 9 & Wikipedia & 44 & 47.3 & 22 & 23.7 & 27 & 29 & 93 & 100 \\
\hline 10 & Smart Board & 54 & 58.1 & 12 & 12.9 & 27 & 29 & 93 & 100 \\
\hline 11 & Google Scholar & 67 & 72.0 & 12 & 12.9 & 14 & 15.1 & 93 & 100 \\
\hline 12 & Edublogs & 39 & 41.9 & 33 & 35.4 & 21 & 22.2 & 93 & 100 \\
\hline 13 & Social Network & 89 & 95.7 & 4 & 4.3 & 0 & 0 & 93 & 100 \\
\hline 14 & Computer Laboratory & 93 & 100 & 0 & 0 & 0 & 0 & 93 & 100 \\
\hline 15 & LCDStand & 78 & 83.9 & 6 & 6.4 & 9 & 9.7 & 93 & 100 \\
\hline 16 & Google search & 89 & 95.7 & 4 & 4.3 & 0 & 0 & 93 & 100 \\
\hline 17 & Bulletin Board & 18 & 19.4 & 43 & 46.2 & 32 & 34.4 & 93 & 100 \\
\hline 18 & Digitalsatelite Channel & 12 & 12.9 & 22 & 23.7 & 60 & 64.5 & 93 & 100 \\
\hline 19 & Video Player/TI & 79 & 84.5 & 14 & 15.1 & 0 & 0 & 93 & 100 \\
\hline 20 & Digital Camera & 83 & 89.2 & 5 & 5.4 & 5 & 5.4 & 93 & 100 \\
\hline 21 & e-library & 69 & 74.2 & 12 & 12.9 & 2 & 2.1 & 93 & 100 \\
\hline 22 & Internet Facilities & 79 & 85 & 13 & 14 & 0 & 0 & 93 & 100 \\
\hline 23 & Ethernet & 87 & 93.6 & 5 & 5.4 & 0 & 0 & 93 & 100 \\
\hline 24 & Open MS Office apps & 92 & 98.9 & 1 & 1.1 & 0 & 0 & 93 & 100 \\
\hline 25 & Web Browser & 83 & 89.2 & 1 & 1.1 & 9 & 9.7 & 93 & 100 \\
\hline
\end{tabular}

Table 2: Level of Availability of E-Learning Technologies for the Teaching and

Learning ofTVETProgrammesinthe Nigerian Coes

The availability of the studied e-learning technologies for the teaching and learning of TVET courses in the Nigerian COEs was presented in Table 2. Analysis of the results from the table revealed that majority of enquired TVET educators reported higher percentage availability of e-learning infrastructure and technologies in their institutions such as: computer laboratory (100\%), computer systems (96.8\%), laptop (94.6\%), power point package (94.6\%), social network (95.7\%), LCD projector and stand (95.7\%), video player/TI (84.5\%), digital camera (89.2\%), internet facilities (85\%),

Ethernet (96.3\%), open MS office app (98.2\%) and web browser (89.2\%). There were moderate availability of smart board (58.1), and Edublogs (41.9\%) as perceived by the enquired TVETeducators.

However, low availability was reported for Wikipedia (24.1\%), Learning Objects (20.4\%), bulletin board (19.4\%), Moodle (3.22\%), iPod and apps (9.3\%), Skype (12.9\%), and Digital satellite channel(12.9\%) as against the high percentage of non-availability of these digital equipment.

4.2. Perception of TVET Educators on the Level of Accessibility of the Studied E-Learning Technologies for the Teaching and Learning ofTVETProgrammes in the Nigerian Coes

The extent to which the studied e-learning technologies are accessible for the purpose of teaching and learning of TVET programmes in the COEs in Nigerian as perceived by the enquiredTVETeducators was presented in Table 3.

As evident from Table 3, majority of enquired TVET educators reported higher percentage accessibility of elearning infrastructure and technologies in their institutions such as: Computer System (77.4\%), Laptop (77.4\%), Power 
Point Package (85\%), Google search (95.5\%), Computer Lab. (93.5\%), Digital camera (72\%), Internet facilities (94.6\%), Open MS Office apps (93.6\%) andWeb browser (88.2\%). The technologies that have moderate accessibility as perceived by the enquired TVET educators were: Social network (68.8\%), E-library (60.2\%), LCD-Projector \& Stand (52.7\%), Video player (56\%) and Wikipedia (34.4\%).

However, low accessibility was reported for: Learning Objects (3.2\%), Ethernet (12.2\%), Smart board (23.7\%), Edublogs (11.8\%), Bulletin board (14\%), Moodle (9.7\%), Skype (16.1\%), and Digital satellite channel (12.9\%) as against the high percentage of non - accessibility of these e- learning technologies.

\begin{tabular}{|c|c|c|c|c|c|c|c|c|c|}
\hline \multirow{2}{*}{\multicolumn{2}{|c|}{$\mathrm{S} / \mathrm{N}$ e -learning technologies }} & \multicolumn{2}{|c|}{ Accessible } & \multicolumn{2}{|c|}{$\begin{array}{c}\text { Not } \\
\text { Accessible }\end{array}$} & \multicolumn{2}{|c|}{ Missing } & \multicolumn{2}{|c|}{ Total } \\
\hline & & $\mathrm{F}$ & $\%$ & $\mathrm{~F}$ & $\%$ & $\mathrm{~F}$ & $\%$ & $\mathrm{~N}$ & $\%$ \\
\hline 1 & Computer System & 72 & 77.4 & 13 & 14 & 8 & 8.6 & 93 & 100 \\
\hline 2 & Laptop & 72 & 77.4 & 10 & 10.8 & 11 & 11.8 & 93 & 100 \\
\hline 3 & College-E-mail Acct. & 29 & 31.2 & 58 & 62.5 & 16 & 17.2 & 93 & 100 \\
\hline 4 & Power Point Package & 79 & 85 & 9 & 9.7 & 5 & 5.4 & 93 & 100 \\
\hline 5 & Moodle & 9 & 9.7 & 80 & 86 & 4 & 4.3 & 93 & 100 \\
\hline 6 & IPod \& Apps & 23 & 36.5 & 58 & 62.4 & 12 & 12.9 & 93 & 100 \\
\hline 7 & Learning-Objects (LOs) & 3 & 3.2 & 62 & 66.7 & 28 & 30.1 & 93 & 100 \\
\hline 8 & Skype & 15 & 16.1 & 49 & 52.7 & 29 & 31.2 & 93 & 100 \\
\hline 9 & Wikipedia & 32 & 34.4 & 47 & 50.5 & 14 & 15.1 & 93 & 100 \\
\hline 10 & Smart Board & 22 & 23.7 & 59 & 63.4 & 12 & 12.9 & 93 & 100 \\
\hline 11 & Google Scholar & 21 & 22.6 & 38 & 41 & 34 & 36.6 & 93 & 100 \\
\hline 12 & Edublogs & 11 & 11.8 & 54 & 58.1 & 28 & 30.1 & 93 & 100 \\
\hline 13 & Social Network & 64 & 68.8 & 13 & 14 & 26 & 28 & 93 & 100 \\
\hline 14 & Computer Laboratory & 87 & 93.5 & 3 & 3.2 & 3 & 3.2 & 93 & 100 \\
\hline 15 & LCD-Projector \& Stand & 49 & 52.7 & 11 & 11.8 & 33 & 35.5 & 93 & 100 \\
\hline 16 & Google search & 89 & 95.7 & 1 & 1.1 & 3 & 3.4 & 93 & 100 \\
\hline 17 & Bulletin Board & 13 & 14 & 21 & 22.6 & 69 & 74.2 & 93 & 100 \\
\hline 18 & Digital-SatelliteChannel & 32 & 34.4 & 21 & 34.4 & 40 & 43 & 93 & 100 \\
\hline 19 & Video Player/TI & 52 & 56 & 17 & 18.3 & 25 & 26.9 & 93 & 100 \\
\hline 20 & Digital Camera & 67 & 72 & 14 & 15.1 & 12 & 13 & 93 & 100 \\
\hline 21 & e-library & 56 & 60.2 & 14 & 15.1 & 23 & 24.7 & 93 & 100 \\
\hline 22 & Internet Facilities & 88 & 94.6 & 1 & 1.1 & 4 & 4.3 & 93 & 100 \\
\hline 23 & Ethernet & 12 & 12.9 & 33 & 35.5 & 48 & 51.6 & 93 & 100 \\
\hline 24 & Open MS Office apps & 87 & 93.6 & 1 & 1.1 & 5 & 5.4 & 93 & 100 \\
\hline 25 & Web Browser & 82 & 88.2 & 1 & 1.1 & 10 & 10.8 & 93 & 100 \\
\hline
\end{tabular}

4.3. Difference in Competence or Level of Expertise of TVET Educators on the Use of ELearning Technologies in the NigerianCoes

\begin{tabular}{|c|c|c|c|c|c|c|}
\hline Variables & $\mathbf{N}$ & Mean & Std. Dev & T-cal & T-tab & Remark \\
\hline Female & 26 & 15.08 & 1.26 & & & \\
\hline Male & 67 & 17.06 & 1.43 & $12.702^{* *}$ & 1.960 & Significant \\
\hline
\end{tabular}

Table 4: Means, Standard Deviations, and T-Test Comparison of Male And Female TVET Educators' Competence/Level Of Expertise On The Use Of E-Learning Technologies In The Nigerian Coes

**Significant; $P=0.05 ; D f=308$

The second hypothesis $\left(\mathrm{H}_{\mathrm{O}} 2\right)$ designed for the research was used to answer the research question $4 \mathrm{~b}$.

- $\mathrm{H}_{\mathrm{O}}$ 2: There is no significant difference between the competence of male and female TVETeducators on the use of elearning technologies in the Nigerian COEs

The result of the independent t-test that compares the competencies or level of expertise on the use ofe-learning technologies between the mean values of the female TVET educators and those of the male TVET educators is shown in Table 9 above. The results showed that Female TVET educatorsobtained a lower mean attitudinal value of 15.08 and a standard deviation of 1.26, while the Malecounterparthad a higher mean value of 17.06and a standard deviation of 1.43. 


\section{Discussion of Findings}

To begin with the Research Question (RQ) 1:

- RQ 1: In what extent are the e-learning technologies available and utilized for the teaching and learning of TVET programmes in the Nigerian COEs?

Analysis and interpretations of the results obtained from this study showed that the potentials for realadoption of elearning technologies for the teaching and learning of TVET programmes in the Nigerian COEs are great. Analysis of the responses to RQ 1 shows that there is reasonable availability of important e-learning technologies across the studied area. Some of the studied e- learning technologies that recorded high percentage of availability are: computer laboratory, computer systems, laptop, power point package, social network, LCD projector and stand, video player/TI, digital camera, internet facilities, Ethernet, open MS office app and web browser. These could be attributed to the government and institutional policy initiatives concerning the adoption ofe-learning technologies in their school systems.

This result is not completely in compliance with the findings of Salawudeen (2010) who reported that Nigerian COEs are evidently confronted with extremely inadequate e-learning infrastructures. However, low levels of availability are reported for some technologies (e.g., Moodle, Learning Objects, Skype, etc.) across the studied area. Though, some of these technologies are specialized developed applications that are used to teach specialized courses. The reason for the inadequate availability of these specialized apps could be lack of technical capacity to develop these technologies by the TVET educators themselves for their specific use.

The findings also revealed that the level of e-learning technologies utilization varies among the research participants, and over $75 \%$ of participants are happy to use e-learning technologies for educational purposes. Most of the studied e-learning technologies are used occasionally (as shown in the Table 3) owing to irregular supply of electricity across the various institutions. However, some of the e-learning technologies are rarely used (such as: Moodle, iPod and apps, Skype, Google scholar, Edublogs, Wikipedia, smart board and bulletin board) due to TVET educators' resistive attitude to change from traditional to modern method of instructional delivery. Other reasons may not be unconnected with the technicality required for their development, applications and usage. This finding is in compliance with Salawudeen (2010), who stated that e-learning are not used in the Nigerian COEs due to highly deficiencies of lecturers in the area of engineering and technologicaldevelopment.

- RQ 2: What is the influence of TVET educators' attitude towards the utilization of e-learning technologies for the teaching and learning of TVET programmes in the Nigerian COEs?

Analysis of results presented in Table 5 indicated that TVET educators have high (above $75 \%$ ) positive attitude towards the utilization of e-learning technologies for their teachings. This positive attitude is an important indicator of willingness and first step in effective e-learning technologies adoption in teaching and learning. As confirmed by the sampled interviewees and other researchersacross the world (e.g. Teo, 2008; Lau \& Yeah, 2008; Huang \& Liaw, 2005), that the teachers attitudetowards e-learning technologies can determine the extent to which e-learning technologies are usedfor teaching and learning purposes. This finding is in agreement with our earlier assertion that thepotentials for real adoption of e-learning technologies for the teaching and learning of TVET programmesinthe Nigerian COEs aregreat.

\section{Conclusion}

Equipping the Nigerian COEs with technology that can produce NCE TVET graduate that will meet the needed stuff required for the $21^{\text {st }}$ century and be globally competitive is highly imperative. Also, adoption of e-learning approach of curriculum delivery in the Nigerian COEs is highly important to provide and train high quality and efficient classroom teachers, inculcating the spirit of enquiry andinnovation in teachers and most importantly instilling skills that can stimulate professionaldevelopment.

\section{Recommendations}

- Modern e-learning technologies and infrastructure should be made available, assessable and usable for all teacher educators across the Nigerian COEs

- More customized e-learning technologies for the teaching and learning of TVET courses should be made available in the Nigerian COEs and TVET educators be professionally trainedon how to use them for their core business.

\section{References}

i. Ajayi,O.and Lawal,B. (2014).An Investigation into Nigerian Pre-ServiceTeachers'

ii. Under-Preparedness to Effectively Teach with Information and Communication Technologies. A paper published in the West African Journal of research in science and education (WAJOSER),Vol. 2. No 1, ISSN 978-0659725-7,June2014.Pg. 58-6.

iii. Bappa-Aliyu, M.(2012). Integrating e-Learning in Technical and VocationalEducation:

iv. A Technical Review. International Journal of Academic Research in Business and SocialSciences, Vol. 2, No. 5, Pg. $52-58$

v. Ekesionye, N. E. \& Okolo, A. N. (2011). Optimizing e-learning opportunities: An effective a n d necessary tool towards re-branding higher education in Nigerian society. In N.Onyegegbuand U. Eze(Eds). Optimizing elearning opportunities for effective educational servicedelivery (pp.269-279).

vi. Gupta, A. (2002).Content Development for eLearning in Engineering Education Interactive Educational Multimedia, number 4 (April 2002), pp. 12-23. http://www.ub.es/multimedia/iem

vii. Lau, T.C. andYeoh, K. H.(2008). Learning behaviour of university's business students in regards to gender and 
levels of study - an exploratory research. Proceedings of InternationalConference of Social Sciences and Humanities. Penang: Universiti Sains Malaysia

viii. Lawal, B.,Ajayi, O. and Salihu, T. (2017). Investigating the barriers to the successful integration ofICT in the teaching and learning process in the Nigerian COEs

ix. Mole A. J. C. (2011). Optimizing e-learning opportunities for effective educational service delivery in Nigeria: Challenges facing library and information professionals (LIPs). In

x. N. Onyegegbu \& U. Eze (Eds.) Optimizing elearning opportunities for effective educational service delivery (pp. 375-385). Enugu: Timex Enterprises for Institute of Education, University of Nigeria Nsukka.

xi. National Policy on Education (2004). Federal Republic of Nigeria Policy on Education (4thed) Lagos NERDC.

xii. OECD (2005). E-learning in tertiary education. Policy brief 2005. Retrieved from http://www.oecd.org/dataoecd/55/25/35961132.(9/202017)

xiii. Obuh, R.O. (2010). Computer Literacy: TheAge Factor.Arim Publishers, Lagos.

xiv. Ogboji, B.A(2011). Status of e-learning usage in Nigerian Universities. In N. Onyegegbu \&U. Eze(Eds.) Optimizing e-learning opportunities for effective educational service delivery (pp.338 - 347) Enugu: Timex Enterprises for Institute of Education, University of Nigeria Nsukka.

xv. Onu, A.J.C. (2011 ). Business Education and emerging ICT. A lead paper presented at themaiden National conference of the Business Educators Association in Vocational Education (BEAVE). At Ahmadu Bello University, Zaria.

xvi. Owolabi, T. O., Oyewole, B. K. and Oke, J. O. (2013) Teacher Education, Information and Communication Technology: Prospects and Challenges of E-Teaching Profession inNigeria.American Journal of Humanities and Social Sciences, 1(2), pp 87-91.

xvii. Ravichandran,V.(2005).E-learning orvirtuallearningthroughVSAT,Apaperpresented at the F19working week in Egypt,pp. 5.

xviii. Salawudeen, O.S. (2010). E-learning Technology. The Nigerian Experience, Roger Printing and Publishing limited,Abuja.

xix. Saud, M. S., Shu'aibu, B., Yahaya, N., Yasin, M. A. (2011). Effective integration of information and communication technologies (ICTs) in technical and vocational education and training (TVE) toward knowledge management in the changing world of work.AfricanJournal of Business Management5(16):6668-6673

xx. Seufart, S., Back,A. and Hauster, M. (2001). E-Learning, Cochbookfor Internet-basedLearning. Smartbook, Zurich.

xxi. Teo, (2008). Pre-service teachers' attitude towards computer use. A Singapore survey. Australian Journal of Educational Technology23(4),pg.413-424

xxii. World Council for Curriculum and Instruction (2012). 9th biennial conference flyer:Curriculum delivery athigher education level: October 16 to 20,2012.

xxiii. Yusuf, M. O.(2007). Trends and barriers on the integration of Informationand

xxiv. Communication Technology in the Nigerian school system. Accepted for publication in Studies in Curriculum, 2007, Department of Curriculum Studies and Instructional Technology, Olabisi Onabanjo University, Ago Iwoye, Nigeria 